\title{
EFEKTIVITAS PEMBERIAN SALEP BONGGOL PISANG AMBON TERHADAP JERAWAT PADA REMAJA
}

\author{
Arfianita Regina Putri ${ }^{1}$, Seftina Lidiya Maharani ${ }^{2}$, Sayyid Nurrohim ${ }^{3}$, Nurul Hidayah ${ }^{4}$ \\ 1,2,3,4 Prodi D3 Keperawatan Akademi Keperawatan PemKab Ngawi \\ *E-mail: nurulridlo@gmail.com
}

\begin{abstract}
Abstrak
Jerawat merupakan salah satu masalah kulit tersering pada remaja, yang disebabkan oleh bakteri Staphylococcus epidermidis, Staphylococcus aureus dan Propionibacterium Acne. Bonggol pisang ambon dapat dijadikan alternatif pengobatan jerawat karena kandungan flavonoid, tanin, dan saponin yang berfungsi sebagai antibiotik, antiseptik, dan merangsang pertumbuhan sel-sel baru. Tujuan penelitian untuk mengetahui efektivitas pemberian salep bonggol pisang ambon terhadap jerawat pada remaja. Metode peneltian: Jenis penelitian Quasi Experiment dengan desain One Group With Pre And Post Test Design. Waktu penelitian bulan April-Juni 2019, di Dusun Mulyorejo, Desa Karang tengah, Kecamatan Ngawi, Kabupaten Ngawi. Jumlah populasi sebesar 120 dengan sampel sebesar 30 responden. Teknik pengambilan sampel mengunakan Purposive Sampling. Responden diberikan salep bonggol pisang ambon dengan konsentrasi 20\%, selama 14 hari berturut-turut, pemakaian setiap pagi, siang, dan malam secara tipis merata. Observasi penyembuhan jerawat dilakukan pada hari ke 7 dan 14 dengan membandingkan keadaan jerawat sebelum dan setelah diberikan salep bonggol pisang. Analisis data menggunakan Che Square. Hasil: Responden yang memakai salep secara rutin memiliki kecenderungan untuk sembuh $(95 \%)$, sedangkan responden yang tidak rutin memakai salep memiliki kecenderungan untuk tidak sembuh $(70 \%)$, dengan nilai p 0,00 $(<0,05)$ dan OR 44,3 Kesimpulan: salep bonggol pisang ambon efektif untuk mengatasi jerawat ringan-sedang pada remaja.
\end{abstract}

Kata kunci: Jerawat Remaja, Salep Bonggol Pisang Ambon.

\begin{abstract}
Effectiveness Of Salep Bonggol Ambon Banana On Acne In Adolescents. Acne vulgaris is one of the most common skin problems in adolescents, which is caused by the bacteri Staphylococcus epidermidis, Staphylococcus aureus and Propionibacterium Acne. Ambon banana humps became alternative acne treatment. Its contains of flavonoids, tannins, and saponins that function as antibiotics, antiseptics, and stimulate the growth of new cells. The study aims to determine the effectiveness of giving Ambon banana hump ointment to acne vulgaris in adolescents. Research method: Type of research is Quasy Experiment with the One Group With Pre And Post Test Design. The research conducted April-June 2019, in Mulyorejo Hamlet, Karang Tengah Village, Ngawi District, Ngawi Regency. The total population: 120 people with a sample of 30 respondents. Sampling technique used purposive sampling. On this study respondents were given Ambon banana hump ointment with a concentration of $20 \%$, every single day until 14th days, proper and equally in every morning, afternoon and evening. Acne vulgaris Observation of healing acne vulgaris was compare of condition on 7th days and 14th days of zits before and after being given banana hump ointment using a scale of physicians global evaluation. Data analysis using Che Square. Results: respondent who used ointment routinely had a tendency on acne vulgaris healing $(95 \%)$ while respondents who did not routinely wear ointments had a tendency to not recover $(70 \%)$ with a $\mathrm{p}$ value of $0.00(<0.05)$ and OR 44.3. Conclusion: Ambon banana hump ointment is effective for treating mildmoderate acne vulgaris in adolescents
\end{abstract}

Keywords: Adolescents Acne Vulgaris, Banana Ambon Hump Ointment. 


\section{Pendahuluan}

Jerawat adalah kondisi abnormal kulit akibat terjadi gangguan berlebihan produksi minyak yang menyebabkan penyumbatan folikel rambut dan pori-pori kulit. Jerawat dapat timbul di kulit muka, bagian dada, leher, dan punggung (Dewi, 2009). Bahaya jerawat jika tidak ditangani adalah bekas luka yang permanen pada wajah, dan juga bisa terjadi infeksi (Septiandari, 2015).

Jerawat sering terjadi pada usia remaja dengan presentasi antara $36-66 \%$ dengan puncak insiden 16-19 tahun pada laki-laki dan 14-17 tahun pada perempuan (Nugroho \& Widyawati, 2013). Dalam suatu penelitian lain didapatkan bahwa prevalensi resiko menderita jerawat lebih tinggi pada perempuan dibandingkan laki-laki pada rentan usia 20 tahun atau lebih (Ika, 2015).

Proses peradangan jerawat terjadi ketika ekskresi bahan kimia dari propionibacterium acne merusak stratum korneum dan stratum germinativum dinding kulit, akibatnya jaringan lemak dan minyak tersumbat sehingga muncul jerawat (Rohmat \& Firdaus, 2018). Penanganan jerawat dapat menggunakan terapi farmakologis seperti pemberian tetrasiklin, eritromisin, doksisiklin, dan klindamisin. Terapi tersebut mempunyai efek samping seperti: iritasi, resistensi, kerusakan organ, dan imunohipersensitivitas.
Menurut penelitian Pongsipulung, Paulina \& Yos (2012) sediaan salep esktrak bonggol pisang ambon dapat menyembuhkan luka terbuka pada mencit jantan karena mengandung senyawa flavonoid, tanin, dan saponin. Pemberian salep dilakukan 3 kali sehari selama 8 hari. Hasil penelitian menunjukkan penyembuhan luka paling signifikan terdapat pada SPBA $20 \%$, yakni mengandung ekstrak bonggol pisang ambon sebanyak 4 gram dari total formulasi salep 20 gram. Penelitian lain oleh Restiana, Siti \& Iit (2016) yang menyatakan bahwa ekstrak etil pelepah pisang ambon memiliki aktivitas anti bakteri terhadap pertumbuhan Propionibacterium acnes dengan konsentrasi yang paling efektif yaitu 20\%. Menurut penelitian Pongsipulung, Paulina \& Yos (2012) dan Restiana, Siti \& Iit, (2016) dapat disimpulkan bahwa bonggol pisang ambon memiliki kemampuan untuk menyembuhan luka pada mencit dan menekan pertumbuhan Propionibacterium acnes. Dari hasil penelitian tersebut juga dapat diketahui potensi bonggol pisang sebagai obat jerawat, sehingga perlu pengembangan penelitian lebih lanjut yang diterapkan pada manusia tentang efektifitas pemberian ekstrak bonggol pisang ambon dalam bentuk sediaan salep antijerawat khususnya pada remaja. Berdasarkan uraian diatas peneliti tertarik untuk melakukan 
penelitian dengan judul efektivitas pemberian salep bonggol pisang ambon terhadap jerawat pada remaja.

\section{Metode}

Jenis penelitian ini adalah Quasi Experiment dengan rancangan One Group With Pre And Post Test Design. Populasi pada penelitian ini sejumlah 125 remaja berjerawat. Jumlah sampel yang diambil sebanyak 30 responden, menggunakan metode purposive sampling. Kriteria inklusi penelitian ini adalah: berusia 14-24 tahun, berjerawat, belum pernah menggunakan salep bonggol pisang ambon sebagai obat jerawat. Kriteria eksklusi: memiliki kulit normal, sudah memakai krim bonggol pisang ambon sebelumnya, penderita pindah domisili dari Dusun Mulyorejo Desa Karangtengah Kecamatan Ngawi, Kabupaten Ngawi. Apabila responden memenuhi kriteri dan bersedia menandatangani informed concent, selanjutnya ditetapkan sebagai subjek penelitian. Penelitian dilakukan di Dusun Mulyorejo Desa Karangtengah Kecamatan Ngawi, Kabupaten Ngawi dan di Laboratorium Farmasi Stikes Bhakti Husada Mulia Madiun untuk proses pembuatan sediaan salep. Penelitian dilakukan selama 3 bulan pada bulan April-Juni 2019.

Penelitian ini terdiri dari 3 tahap, yaitu tahap persiapan penelitian, tahap pelaksanaan penelitian dan tahap analisis data. Tahap persiapan terdiri dari: proses persiapan bahan baku penelitian, meliputi pembelian bahan bonggol pisang ambon di petani yang kemudian diekstrak menggunakan metode sokhlet dan dibuat sediaan kental (Pongsipulung, Paulina \& Yos, 2012). Dari sediaan kental selanjutnya dilakukan uji kadar flavonoid, Tanin dan Saponin, di laboratorium STIKES Bhakti Husada Mulia Madiun, kemudian dibuat sediaan salep jerawat. Selain itu dilakukan test alergi penggunaan salep bonggol pisang ambon ke beberapa remaja berjerawat sebelum diberikan ke responden penelitian. Pada tahap ini juga dipersiapkan surat izin penelitian berupa etichal clearance di RS Moewardi Solo, dan ke Kesbangpolinmas Kabupaten Ngawi. Selain itu disiapkan kuesioner data dasar penelitian, yang berisi identitas, usia, jenis kelamin responden. Pada tahap pelaksanaan penelitian ini terdiri dari 3 tahap, yaitu: Penentuan subjek penelitian sesuai kriteria inklusi-ekslusi. Pada responden terpilih kemudian ditentukan derajat dan klasifikasi jerawatnya menggunakan skala ordinal berdasarkan penelitian Nugroho (2013), yaitu: (1). Jerawat meradang ringan dengan jumlah papul $<10$ pada satu sisi wajah (Derajat I), (2) Jerawat meradang sedang, jumlah papul 10-30 pada satu sisi wajah (Derajat II dan III), dan (3) Jerawat meradang berat, jumlah papul >30 pada satu sisi wajah (Derajat IV). Pada tahap pelaksanaan juga dilakukan penjelasan penelitian yang diikuti 
dengan penandatangaan informed concern penelitian, pengkajian data dasar responden menggunakan quesiner, pemberian salep bonggol pisang ambon pada responden, dan evaluasi jerawat pada responden pada akhir minggu pertama dan akhir minggu kedua menggunakan dokumentasi foto pada area yang berjerawat dengan nilai kesembuhan : sembuh jika jumlah papul 50\%-100\%, dan belum sembuh jika jumlah papul 0\%-49,9\%.

Analisis data penelitian terdiri dari analisis univariat, dan bivariat. Analisis Univariat untuk mendeskripsikan karakteristik masing-masing variabel yang diteliti. Analisis Bivariat menggunakan uji Chi-square. Variabel independen pada penelitian adalah efektivitas pemberian salep bonggol pisang ambon, variabel dependen penelitian adalah jerawat pada remaja. Variabel Confounding penelitian ini adalah genetik, hormon, makanan, keaktifan kelenjar sebasea, psikis, musim, stress, infeksi bakteri p. acne kosmetik.

\section{Hasil}

\section{Karakteristik dasar responden}

Karakteristik subjek penelitian ini meliputi: usia, jenis kelamin, dan pendidikan disajikan pada tabel 1 .
Tabel.1 Karakteristik Responden

\begin{tabular}{lcc}
\hline Karakteristik & Responden & \\
\cline { 2 - 3 } & $\mathbf{N}$ & $\mathbf{\%}$ \\
\hline Usia (tahun) & & \\
$\begin{array}{l}\text { Remaja awal } \\
\text { (11-13 tahun) }\end{array}$ & 0 & 0 \\
$\begin{array}{l}\text { Remaja pertengahan } \\
\text { (14-18 tahun) }\end{array}$ & 10 & 33,33 \\
Remaja akhir & & \\
(19-24 tahun) & 20 & 66,67 \\
Jenis kelamin & & \\
Laki-laki & 11 & 36,7 \\
Perempuan & 19 & 63,3 \\
Pendidikan & & \\
SMP & 1 & 3,33 \\
SMA & 8 & 26,67 \\
Perguruan Tinggi & 16 & 53,33 \\
Bekerja & 5 & 16,67 \\
\hline Sumber: Data primer & &
\end{tabular}

Berdasarkan tabel.1 diketahui sebagian besar responden berjenis kelamin perempuan sebesar $19(63,3 \%)$ dan 11 orang $(36,7 \%)$ berjenis kelamin laki-laki. Adapun kasus jerawat banyak dijumpai pada remaja usia akhir dengan persentase $66,67 \%$ sebanyak 20 orang dan remaja usia pertengahan dengan persentase $33,33 \%$ sebanyak 10 orang. Ratarata responden dalam penelitian ini menderita jerawat tipe ringan sebesar $70 \%$ dan jerawat tipe sedang sebesar $30 \%$. Pada penelitian ini responden yang masih sekolah di jenjang SMP sebanyak 1 orang $(3,33 \%)$, SMA sebanyak 8 orang $(26,67 \%)$, perguruan tinggi sebanyak 16 orang $(53,33 \%)$, dan yang telah bekerja sebanyak 5 orang $(16,67 \%)$ 


\section{Proses ekstraksi, Uji Fitokimia, Pembuatan salep bonggol pisang, dan Uji Alergi}

a. Bahan dan Alat

Bahan yang digunakan bonggol pisang ambon yang telah berbuah, ethanol $70 \%$, aqua bidest, vaseline album, adeps lanae. Alat yang digunakan timbangan analitik, mesin sokletasi, rotary evaporator, waterbath, dan mortir

\section{b. Pembuatan Ekstrak}

Bonggol pisang ambon dicuci bersih dan dipotong tipis kemudian dijemur sampai kering dan terhindar dari sinar matahari langsung, kemudian blender sampai halus (Serbuk simplisia). Proses estraksi dilakukan dengan mengambil $50 \mathrm{~g}$ serbuk simplisia yang di soklet dengan alkohol 70\% sebanyak 3 kali sirkulasi. Ekstrak cair hasil sokletasi di pekatkan menggunakan rotary evaporator untuk selanjutnya diuapkan di atas waterbath, ektrak cair tersebut akan berubah tekstur menjadi lebih padat yang disebut dengan ekstrak kental.

c. Uji Kandungan Fitokimia

Hasil pengujian golongan senyawa fitokimia pada ekstrak kental bonggol pisang ambon menggunakan uji kualitatif metode pewarnaan menunjukan bahwa ekstrak tersebut mengandung tanin, saponin, dan flavonoid. Adanya tanin dibuktikan dengan cara sebanyak 0,1 gram ekstrak kental ditambahkan FeCL 1\% kemudian diaduk dan dilanjutkan dengan larutan $\mathrm{H} 2 \mathrm{SO} 4$ pekat dan diperoleh endapan berwarna coklat. Hasil uji saponin menunjukan tinggi busa $\pm 1 \mathrm{~cm}$. Uji flavonoid ditunjukan dengan adanya warna merah setelah ditambahkan $\mathrm{HCl}$, ethanol 96\% dan serbuk MG.

\section{d. Formulasi Sediaan Salep}

Formulasi salep ekstrak bonggol pisang ambon dengan konsentrasi $20 \%$, dibuat dari ekstrak bonggol pisang $1 \mathrm{~g}$, adeps lanae $0,6 \mathrm{~g}$, vaseline album 3,4 g, aquades $1 \mathrm{gtt}$, m.f. salep 5 g. proses pembuatan salep diawali dengan menimbang bahan sebanyak 30 gram ekstrak kental, 34 gram vaselin album, dan 6 gram adeps lanae. Kemudian bahan-bahan dimasukkan kedalam mortir dengan urutan adeps lanae terlebih dahulu dilanjutkan dengan vaselin album dan ekstrak kental, semua bahan tersebut diaduk hingga homogen.

e. Uji Sedian Fisik Salep

Hasil uji daya lekat salep dengan 3 kali replikasi menunjukan pada replikasi pertama membutuhkan waktu 1,16 detik melekat. Replikasi kedua 1,05 detik dan replikasi ketiga 1.14 detik. Uji daya sebar dengan 3 kali replikasi tersaji pada tabel 2 .

\section{Tabel.2 Hasil Uji Daya Sebar}

\begin{tabular}{ccccc}
\hline \multirow{2}{*}{ Replikasi } & \multicolumn{4}{c}{ Beban yang digunakan (gram) } \\
\cline { 2 - 5 } & 0 & 50 & 100 & 150 \\
\hline 1 & $4,33 \mathrm{~cm}$ & 4,5 & 4,73 & 4,87 \\
2 & $3,77 \mathrm{~cm}$ & 4,27 & 4,6 & 4,97 \\
3 & $3,63 \mathrm{~cm}$ & 4,63 & 4,67 & 4,87 \\
\hline \multicolumn{5}{l}{ Sumber: Data primer }
\end{tabular}

Sumber: Data primer 
Dari data diatas menunjukan daya sebar salep bonggol pisang ambon memiliki daya sebar rata-rata sebesar $4,68 \mathrm{~cm}$.

Uji homogenitas pada salep bonggol pisang ambon menunjukan bahwa salep tersebut homogenitasnya kurang karena ekstrak sulit untuk dihomogenkan. Hasil uji organoleptis menunjukan bahwa warna salep coklat, berbentuk masa lembek, dan bau khas adeps lanae. Uji $\mathrm{Ph}$ salep bonggol pisang ambon menunjukan angka 4.8. Uji viskositas salep bonggol pisang ambon dengan alat Viskositas Brookfield, spindel yang digunakan bernomer 6 dan kecepatan 20 rpm. Menunjukan hasil $10.000 \mathrm{cp}$.

\section{f. Uji Alergi}

Uji alergi dilakukan pada remaja berjerawat sebanyak 6 orang selain responden terpilih untuk mengetahui potensi alergi yag ditimbulkan akibat pemakaian salep jerawat, seperti rasa gatal, panas terbakar, munculnya ruam kemerahan disekitar daerah yang diberi salep. Pemberian salep dilakukan $3 x$ sehari selama 3 hari berturut. Dari 6 responden tidak ada yang alergi.

\section{Hasil Analisis Univariat}

Distribusi frekuensi klasifikasi jerawat pada responden sebelum diberikan salep bonggol pisang ambon adalah jerawat ringan sebesar $21(70 \%)$ responden, dan jerawat sedang $9(30 \%)$ responden. Distribusi frekuensi tingkat kesembuhan jerawat responden setelah diberikan salep bonggol pisang ambon adalah sembuh $22(73,3 \%)$, belum sembuh $8(2,6 \%)$

\section{Hasil Analisis Bivariat.}

Analisis bivariat menggunakan uji chisquare, hasil dapat dilihat dari tabel 3

\section{Tabel 3. Hasil analisis bivariat efektivitas pemberian salep bonggol pisang ambon terhadap jerawat remaja.}

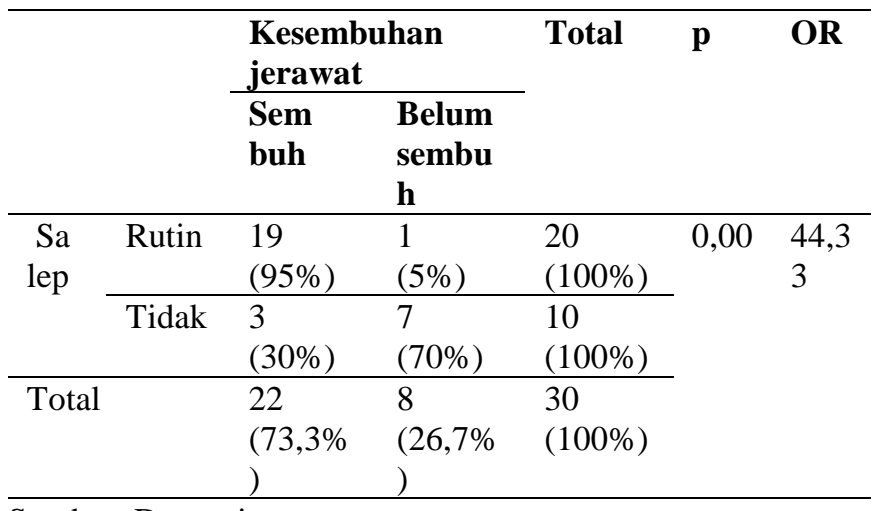

Sumber: Data primer

Dari tabel diatas dapat diketahui Responden yang memakai salep secara rutin memiliki kecenderungan untuk sembuh (95\%), sedangkan responden yang tidak rutin memakai salep memiliki kecenderungan untuk tidak sembuh (70\%), dengan nilai $\mathrm{p} 0,00$ $(<0,05)$. Odd Ratio 44 dari tabel menunjukan bahwa responden yang menggunakan salep secara rutin mempunyai peluang untuk sembuh sebesar 44 kali lebih banyak dibandingkan dengan yang tidak memakai salep secara rutin. 


\section{Pembahasan}

Pada karakteristik dasar responden, sebagian besar responden berjerawat adalah wanita dan berusia remaja. Hal ini sesuai dengan penelitian Nugroho \& Widayati (2013), yang menyatakan bahwa jerawat sering terjadi pada usia remaja dengan presentasi antara 36-66\% dengan puncak insiden 16-19 tahun pada laki-laki dan 14-17 tahun pada perempuan. Penelitian serupa oleh Ika (2015) mengatakan bahwa prevalensi penderita jerawat lebih tinggi pada perempuan dibandingkan laki-laki pada rentan usia 20 tahun atau lebih. Selain itu salah satu faktor tersering munculnya jerawat pada wanita adalah faktor hormonal, dimana setiap bulannya wanita akan mengalami siklus haid yang berdampak pada ketidak seimbangan estrogen dan progesteron terhadap munculnya jerawat. Saat mestruasi hormon estrogen akan menurun yang dapat memicu peningkatan aktivitas kelenjar sebasea (Indrawan \& Kusumastuti, 2013). Pemakaian kosmetik juga berpengaruh terhadap munculnya jerawat pada wanita, penelitian yang dilakukan oleh Mao, Van, Keen, Schmitz \& Gershwin (2000) menyebutkan pelembab dan alas bedak dapat menimbulkan jerawat karena mengandung bahan yang bersifat komedogenik. Keadaan Penelitian lain juga menyebutkan stres yang meningkat dapat memperparah kondisi jerawat hal tersebut dikarenakan stres dapat merubah fungsi ketebalan barier kulit (Ika, 2015).

Kondisi kulit yang berminyak merupakan kondisi yang mendukung tumbuhnya jerawat, karena kulit berminyak mencerminkan peningkatan aktivitas kelenjar sebasea yang dapat menjadi tempat berkembangnya bakteri p. acne (Indrawan \& Kusumastuti, 2013). Riwayat keluarga merupakan faktor yang berpengaruh terhadap jerawat bahwa $80 \%$ remaja berjerawat memiliki riwayat acne vulgaris pada keluarganya (Klaus, Richard \& Dick, 2005).

Untuk uji sediaan fisik salep bonggol pisang ambon meliputi uji daya lekat, daya sebar, organoleptis, viskositas dan Ph. Hasil uji daya lekat salep dengan 3 kali replikasi menunjukan pada replikasi pertama membutuhkan waktu 1,16 detik melekat. Replikasi kedua 1,05 detik dan replikasi ketiga 1.14 detik. Dari data tersebut menunjukan bahwa salep bonggol pisang ambon tidak memenuhi syarat uji daya lekat yakni tidak boleh kurang dari 4 detik (Fatimah, 2017). Uji homogenitas pada salep bonggol pisang ambon menunjukan bahwa salep tersebut homogenitasnya kurang hal ini ditandai dengan adanya butiran kasar atau partikel yang bergerombol pada objek gelas (Fatimah, 2017). Hasil uji organoleptis menunjukan 
bahwa salep berwarna coklat, berbentuk masa lembek, dan memiliki bau khas adeps lanae. Hal ini dikarenakan salep berbasis salep hidrokarbon. Hal tersebut berkebalikan dengan penelitian yang dilakukan oleh Fatimah (2017) yang menyatakan bahwa bau khas sediaan salep ekstrak bonggol pisang ambon adalah bau bonggol pisang ambon itu sendiri. Uji viskositas salep bonggol pisang ambon dengan alat Viskositas Brookfield, spindel yang digunakan bernomer 6 dan kecepatan 20 rpm. Menunjukan hasil 10.000 cP. Adapun Uji $\mathrm{Ph}$ salep bonggol pisang ambon menunjukan angka 4.8 yang dimana sudah memenuhi syarat kelayakan sediaan topikal yakni antara 4,5 sampai 6,5 (Anief, 2006).

Pada analisis bivariat hasil penelitian ini menunjukkan bahwa responden yang memakai salep secara rutin memiliki kecenderungan untuk sembuh dibandingkan dengan yang tidak menggunakan salep secara rutin. Hal ini sejalan dengan penelitian Pangsipulum, Paulina \& Yos (2012) yang menyatakan bahwa bonggol pisang mampu menyembuhkan luka terbuka pada mencit jantan karena kandungan flavonoid, tanin, dan saponin. Flavonoid mempunyai kemampuan untuk merusakan permeabilitas dinding sel bakteri, mikrosom dan lisosom sehingga bakteri mati. Tanin mempunyai kemampuan Antiseptik pada permukaan luka, dan bekerja sebagai bakteriostatik, sehingga mencegah terjadinya infeksi. Saponin berfungsi merangsang pertumbuhan sel-sel baru. Penelitian serupa yang dilakukan oleh Restiana, Siti \& Iit (2016) menyatakan bahwa ekstrak etil dari pelepah pisang ambon memiliki aktivitas anti bakteri terhadap pertumbuhan Propionibacterium acnes dengan konsentrasi yang paling efektif yaitu $20 \%$. Mendasar pada kedua penelitian tersebut menurut peneliti dengan adanya kandungan Flavonoid, Tanin dan Saponin pada bonggol pisang dan kemampuan bonggol pisang untuk menekan pertumbuhan bakteri Propionibacterium acnes yang merupakan salah satu bakteri penyebab terbanyak jerawat, sehingga salep bonggol pisang ini menjadi efektif untuk mengobati jerawat. Selain itu keberhasilan pengobatan jerawat ditentukan oleh kepatuhan responden dalam pemakaian salep setiap hari sesuai dengan arahan peneliti. Hal ini didukung oleh penelitian yang dilakukan oleh Alvin (2014) yang menyatakan bahwa faktor sikap peneliti, norma subjektif, dan kontrol perilaku sangat berpengaruh pada kelangsungan penelitian.

\section{Kesimpulan}

Berdasarkan hasil penelitian dapat disimpulkan bahwa salep onggol pisang ambon efektif untuk mengatasi jerawat pada remaja. 


\section{Saran}

Perlu penelitian lebih lanjut mengenai bentuk sediaan salep agar homogen dan memiliki daya lekat yang baik lebih baik, serta penambahan bahan tambahan berupa zat wangi agar bau khas adeps lanae tidar terlalu menyengat. Perlu dikembangkan penelitian pada responden dengan jerawat berat

\section{Ucapan Terimakasih}

Ucapan terimakasih kami sampaikan kepada Kementrian Riset, Teknologi, dan Pendidikan Tinggi Republik Indonesia yang telah membiayai penelitian ini. Dinas Kesehatan Kabupaten Ngawi, LPPM dan Bidang kemahasiswaan Akper Pemkab Ngawi yang telah memfasilitasi pelaksanaan penelitian

\section{Referensi}

Alvin, A. (2014). Pengaruh sikap, norma subyektif, dan kontrol perilaku yang dipersepsikan staff pajak terhadap kepatuhan pajak wajib pajak badan. Journal Tax \& Accounting Review, 4(1). publication.petra.ac.id.

Anief, M. (2006). Farmasetika. Yogyakarta: Gajah Mada University Press.

Dewi, S.A. (2009). Cara Ampuh Mengobati Jerawat. Jakarta: Buana Indonesia.
Fatimah,Y. (2017). Pengaruh basis salep terhadap sifat fisik sediaan salep ekstrak bonggol pisag ambon (Musa Paradisiaca varsepientum L.) sebagai penyembuhan luka terbuka pada tikus. Fakultas Farmasi Universitas Surakarta

Surakarta.http://eprints.ums.ac.id diakses pada 16 Juni 2019

Ika. (2015). Hubungan tingkat stres dengan timbulnya jerawat pada siswa smpn 4 ngawi. Fakultas Kedokteran Universitas Muhamadiyah: Surakarta. http://eprints.ums.ac.id/id/eprint/39380.

Indrawan, N dan Kusumastuti, A.C. (2013). Hubungan lemak jenuh dengan kejadian acne vulgaris. Journal of Nutrition College, 2(4), 578-584. http://ejournalsl.undip.ac.id/index.php/jnc

Klaus, W., Richard, A. dan Dick, S. (2005). Fitz Patrick's colour atlas and sinopsis of clinical dermatology. New York: Medical Publishing Division.

Mao, T., Van, D.W., Keen, C.L., Schmitz, H.H. dan Gershwin, M.E. (2000). Cocoa procyannindins and human cytokine transcription and secretion. $J$ Nutr, 130:209S-9S.

Nugroho, R.A., dan Widayati, R.I. (2013). Terapi topikal clindamycin dibandingkan dengan niacinamidet zinc pada acne vulgaris. Skripsi. Fakultas Kedokteran Universitas Diponegoro: Semarang. 
Pongsipulung, G.R., Paulina, V.Y.Y., dan Yos, B. (2012). Formulasi dan pengujian salep ekstrak bonggol pisang ambon (musa pradisiaca var. Sapientum(1.)) terhadap luka terbuka pada kulit tikus putih jantan galur wiatar (rattus norvegicus). Jurnal Ilmiah Pharmacon 1(2), 7-13.

https://ejournal.unsrat.ac.id/index.php/phar macon/article/view/462/370.

Restiana, E., Siti, K., dan Iit, F. (2016). Uji aktivitas antibakteri ekstrak etil asetat pelepah pisang ambon (musa paradisiaca 1.) Terhadap propionibacterium acnes. Jurnal Cerebellum, 2(2), 422433.http://jurnal.untan.ac.id/index.php/jfk/a rticl e/view/24342
Rohmat, N. dan Firdaus. (2018). Uji aktivitas antibakteri ekstrak tepung kulit buah pisang ambon (musa paradisiaca) terhadap propionibacterium acne atcc 1223 dan staphylococcus epidermidis atcc 12228. http://repository.unvary.ac.id/xmlui/handle/ $123456789 / 216$

Septiandari, V.K. (2015). Pengaruh ekstrakdaun kemangi (ocimum apericanum 1.) Terhadap pertumbuhan bakteri propionibacterium acne dan pemanfaatannya sebagai buku non-teks. Fakultas Keguruan dan Ilmu Pendidikan Universitas Jember: Jember. http://respository.unej.ac.id/handle/1234567 89/71392. 